Krynski, A. (2019). In a State of Fragility: The Compromised Dignity of Communities, Indignation, and the Incapacitation of Public Education

\title{
In a State of Fragility: The Compromised Dignity of Communities, Indignation, and the Incapacitation of Public Education
}

\author{
Agnes Krynski* \\ Eastern Michigan University \\ *Corresponding Author: akrynski@emich.edu \\ Received : 2019-10-01 \\ Accepted : 2019-11-01
}

How to cite this paper: Krynski, A. (2019). In a state of fragility: The compromised dignity of communities, indignation, and the incapacitation of public education. Journal of Culture and Values in Education, 2(3), 1-24.

\begin{abstract}
The dominant ideological and material framing of the work of public school communities in the United States prevents schools from contesting the indignities they themselves or their neighbors suffer. Leaving this frame intact means permitting exclusionary policies and violent practices to incapacitate learning communities to work toward the attainment of inclusive democracy. Inclusive communities understand themselves to be in connection with other historically delineated groups in a web of affiliation and care. Communities that flourish as other communities wither compromise their own self-respect when they do not call out such injustice. Learning communities can redefine the work they do through an institutionally-grown advocacy of connection that actively nurtures intercommunity solidarity. I situate this reorientation within a tradition of thinking about civic agency, dissent, and indignation. I then suggest that public institutions carve out an ethos of connection as a source of selfunderstanding to take on the task of informal ethical oversight. Such a community ethos encourages schools to respond to economic, environmental, and social realities and to recognize, respect, and work through past and present civic grievances relationally.
\end{abstract}

Keywords: Inequality, Indignation, Dignity, Advocacy

\section{Introduction}

We have learned to respond to manifestations of extreme inequality such as homelessness the way communities have, during certain eras, been directed to respond to leprosy. Persons of health and wealth mobilize to contain, to exclude, to marginalize. The affected are relegated to modern-day lepers' colonies, left to fend for themselves while managing to create needsbased communities spun with the sturdy fabric of mutual aid and sewn with the needle of solidarity. Yet, all the wealthy see, while shielding themselves with handkerchiefs, are vagabonds and trespassers. The exiled wanderers are tolerated outside the gates of the city as long as they keep moving when the wealthy come to reclaim their land for those deemed to be worthier residents. Until one day, in the advent of a whole system collapse, the healthy are caught off guard when what they are faced with is no longer manageable leprosy, but the 
Krynski, A. (2019). In a State of Fragility: The Compromised Dignity of Communities, Indignation, and the Incapacitation of Public Education

plague. And there is no escaping the plague. It cannot be contained. The affected cannot be excluded. The death the plague brings spills over the margins. Joining the caravan heading into unknown lands, the wealthy succumb in equal measure. In a state of delirium, they realize that the fortress they thought would afford them total immunity is a fragile sand castle indeed.

We all live in a world defined by states of fragility with a variety of plague-like crises on our collective horizon. The fragility of the state of democracy is never more evident than in folding times. Intermittent watershed events increase in number and magnitude and cause us to reconsider the path we are taking. This inquiry takes a variety of forms. Many ask if the state is doing enough with our ample financial contributions. We judge whether these funds are applied justly to our collective societal project. We weigh how well our representatives advocate for our communities. At our civic best, we inquire about the well-being of those communities in which we do not put our children to bed. We care about the viability of those times in which we personally will not have to breathe and drink. Finding clarity about what matters to us now and concern about the legacy we will leave for kin and non-kin alike leads us to evaluate the quality of state responsiveness to the crises of our times as a criterion of legitimacy. It is through this evaluation that we enact our civic agency. For in the absence of an established civic practice of contestation, even if a degree of meaningful structural change occurs, diminished public participation contributes to unbalanced political representation.

Protest emerges as an attempt to redress this imbalance. Youth-led social movements draw everyone's attention to future impacts of current decision-making. We are confronted with the question of who is most affected by the indifference and inaction of representatives. For we know that legal and political equality alone does not prevent blight from being suffered disproportionately. Acknowledging the precariousness of representative democracy leads us to ask what the consequences are if successive administrations governing a country fail to attend to systemic suffering and display no desire to alleviate it. Such a society needs to confront a growing cascade of critical questions. Why is such a tradition of governance, and the society of apparent indifference upholding it, not discredited in the mind of every citizen? What prospects does a democratic society hold if it, in turn, delegitimizes the raising of this question by its citizens? And what if the dominant framing of public education undermines the very nature of democratic citizenship and prevents schools from contesting inequality? Within such a narrow field of action, how are schools to promote just ways of being and working in community with others?

In the following, from my place as an educator in the United States working within a public education system steeped in residential segregation and exclusivity of access to educational opportunities, I argue that thinking about the value of dignity, public outcries motivated by indignation, and institutional incapacitation is necessary to make sense of how learning communities can respond to wider exclusionary developments. A public education of shared aims and easily mitigated vulnerabilities is based in a sense of association that confers an obligation to strive for equal respect for and value of all who partake of it. 
Krynski, A. (2019). In a State of Fragility: The Compromised Dignity of Communities, Indignation, and the Incapacitation of Public Education

My concerns translate into two related objectives for this article. First, I want to contextualize my argument in a discussion of larger cultural conditions as they come to bear on public education. Second, I want to propose the outlines of a theoretical model of the work of learning communities and wider communities as advocatory, relational, and responsive to an era's given cultural conditions. The need for such a commitment rests on the pedagogical value of teaching about and through democratic civic contestation of unequal economic and social living conditions anywhere in the web of affiliation. It also depends on a refutation of the often dangerously concomitant exclusionary and authoritarian voices presenting themselves as solutions to unjust and inhumane conditions affecting parts of the polity. These attempts at group appeasement hearken back to the spirit of segregation. They rely on fragmentation of the demos as both method and desired outcome and legitimize indifference to the fate of oppressed communities. As they coalesce into an explanatory framework, these efforts deny the effects of specific historical trajectories and their colonizing, enslaving, and segregating initiators and promulgators. Yet, it is these histories that predict and constrain group attainment of highly coveted community characteristics such as relative personal safety and readily available material resources.

The impetus for my analysis is Zygmunt Bauman's interrogation of the dilemmas that continually pose a challenge to the ideal of a just society and that, I believe, public schools should help students understand and take to heart: moral indifference (Bauman, 2013; Bauman \& Donskis, 2013, 2016) and the fragile creation of community at the nexus of freedom and security with security often winning the upper hand (Bauman, 2001). Through Ulrich Beck's identification of shared vulnerabilities as inherent in a "(world) risk society" (Beck, 1992, 1999, 2009) and his delineation of "metamorphosis" (Beck, 2016) as a construct denoting the destabilization of epistemological certainty about the world in which we live, I think about schools as institutions affected by and embedded within an ever-changing and often elusive cultural, material, and emotional landscape, often clearer in retrospect than in real time. I turn to James Jasper's (2018) work around political emotions and his conception of emotions as essential to understanding civic protest and political action in order to arrive at a clearer understanding of this landscape as it relates to education. Of illustrative value and of particular interest to me in tracing the need for a public school ethos of intercommunity connection and solidarity is a converging line of inquiry about the causes of worldwide indignation as indicators and catalysts of a variety of ethical crises of our times (Appadurai, 2017; Fraser, 2017; Hochschild, 2016; Kimmel, 2017). As these ethical crises often mask as mere political upsets, revisiting how civic actors have successfully unmasked injustices before is a worthwhile pedagogical endeavor.

In the second part of this essay, I consider how educational practice and institutionally-grown advocacy can repudiate proposed solutions that do harm to a vision of democratic political community. I ask how we can incorporate ethical responsiveness and awareness of structural group inequality (Anderson, 2010; Tilly, 1998) and the emotions driving collective agency (Jasper, 2018) into a meaningful public school ethos. Following Nick Couldry's (2010) articulation of a contemporary "crisis of voice" (p. 1) and the need for the renewal of "public voices" (p. 140), such an ethos requires and enables educators to call out the disproportionate 
Krynski, A. (2019). In a State of Fragility: The Compromised Dignity of Communities, Indignation, and the Incapacitation of Public Education

impact under which impoverished communities endure violence of various sorts, ranging from conceded bodily well-being due to targeted environmental degradation (Taylor, 2014) to impeded community meaning-making through eliminating schools as community support hubs (Ewing, 2018). Such an ethos also requires educators to repudiate a dehumanizing economic system that betrays working class communities and fuels resentment that divides (Williams, 2017). I argue that well-off communities that do not acknowledge those sources of suffering that suppress their neighbors' flourishing compromise their own dignity in the process. True communities of excellence-an image that affluent communities work tirelessly to project-do not cultivate the success of their own at the expense of the thriving of other historically delineated groups. Instead, dignified communities refuse to benefit from what Eddie Glaude (2017) calls a "value gap" (p. 34), which he understands to be a pernicious organizing principle of white people mattering the most by design. This principle of competition by way of exclusion and segregation sustains what Elizabeth Anderson (2010) terms a "racialized social hierarchy" (p. 187). We can trace this hierarchy to powerful historical processes, exemplified in, just to cite one prominent example, Noel Ignatiev's (2009) classic study of the phenomenon of Irish identity and caste transformation and his key observation that for the Irish "to enter the white race was a strategy to secure an advantage in a competitive society" (p. 3). Securing such an advantage persists as an objective for communities with various degrees of economic power and political clout. Competition as a motivating force is an impediment to inclusive democracy. Schools, however, have been made to compete for resources and students. As this competitive thinking takes hold of educational institutions, it becomes naturalized in school curricula and a community's self-understanding. Seeking a pedagogical response to such realities, I want to think of school districts as epistemic centers of community knowledge and understanding. Schools sustain a community's beliefs and opinions about itself and guide how its members learn to relate to other communities. Schools can be places in which we nurture a responsive public school ethos that centers mutuality and relationality to other communities as central to a learning community's mission.

\section{Democracy, Dissent, and an Ever More Fragile Public Education}

Carving out a responsive public school ethos requires an understanding of the nature of dissent and the role it plays in creating relationships that sustain the democratic project. What schools need to address is this core phenomenon: A world of ever-increasing vulnerability and continuous inequality causes us to grow skeptical about the legitimacy of our representatives' decision-making. Whatever their entry point, many people engage in some form of spontaneous critique of such realities. Whether raw or more deliberate, this evaluation manifests itself in a variety of attitudes toward our larger societal endeavor. The nature of our critique depends on how we understand our positionality within this project. Our beliefs about belonging to a greater political community affect the stance we take in the face of injustice. A public education that does not help students articulate these critiques is becoming ever more brittle.

We know that endeavors that aim to contest the legitimacy of influential policies and practices do not take root in all soils. Whereas a totalitarian government's source of legitimacy, once 
Krynski, A. (2019). In a State of Fragility: The Compromised Dignity of Communities, Indignation, and the Incapacitation of Public Education

obtained through violence, remains the threat of renewed retributive violence at the hand of the state, a democratically elected government has to ensure it stays legitimate in the eyes of its citizens through much less forceful means. It is a totalitarian government's prime objective to rule with an iron fist to build a tower of legitimacy that cannot be reached, budged, or questioned. An uncritical support of repressive nation-state policies contributes to the building of ever higher towers. In contrast to such authoritarianism, a democratic project needs to support dissent because the state must not be so fragile as to break, but not so solid that it fails to yield to widely desired change. As an integral part of the democratic process, the inherent fragility of legitimacy necessitates continuous oversight by the people. Hence, in a democratically-oriented society, governance is held in balance through democratic acts of legitimization and contestation. As the people bestow initial legitimacy on government, so is maintaining that legitimacy predicated upon government establishing conditions of trust and well-being. A vote of no confidence is never far off after the initial stamp of approval the people may have given. Constituting a regulatory democratic tension, such unease contributes to the state of fragility characteristic of a state born or reimagined under the aegis of democratic ideals. Schools that pay attention to these processes understand themselves to be at the heart of this regulatory impulse.

These ideals are at stake if this already fragile legitimacy is slowly but surely eroded as a result of government inaction, and by extension inaction on the part of institutions of public education, in the face of moral and material matters such as systemic poverty and environmental degradation. Ever weary of being at the peril of losing a broad mandate because of its potential inability to foster well-being for all, a democratically elected government has to chart a course that reconciles measured authority with democratic freedoms. For it is up to the art of democratic governance that the tension between holding power and the uncertainty of governing with a temporary mandate not be cause for opting for authoritarian and totalitarian methods. The stronger the state feels it needs to be and the more afraid it is about being delicately nested, the more likely it is to resort to principles and procedures of strict orderliness, perpetual fabrication of crises, and desperate attempts at internal and external fortification. Many school districts, currently upheld by hierarchical structures, share similar characteristics and motivations.

\section{The Pedagogical Value of Teaching about Civic Contestation Efforts}

Learning about the phenomenon of democratic dissent and the democratic undercurrents of legitimacy of governance means understanding that there have been many times in the past in which it was vital for those who reside within communities of various scales to strengthen their standing in the eyes of their government through actions that preserved democratic structures and modes of being. The question at the heart of this continuing process is: Which principles, procedures, relationships, practices, and outcomes inherent in governance are legitimate and which are not? This is in essence also a pedagogical question that alludes to the constant negotiation and renegotiation of trust and distrust, voice and silencing, as well as autonomy and coercion that is on many communities' daily agenda. 
Krynski, A. (2019). In a State of Fragility: The Compromised Dignity of Communities, Indignation, and the Incapacitation of Public Education

Animated by this question, distrust of centralized government and of public schools has been a long-time reality for many marginalized groups. This marginalization prevented those engaged in opposition efforts from seriously threatening the stability, maintained at any cost, of the Western nation-state and the schools that sustained its guiding images. In this political context, successive administrations, designated and legitimized by the electorate, failed to extend the curtesy of codified agency to groups with interests different from those of the democratic majority. Yet, Stephen Pimpare (2008) describes historical cases in which "indignity is rightly met with rebellion, resistance, insolence, and indignation" (p. 205): food riots in times of economic depression, petitions for the implementation of public works, protest marches in response to pervasive unemployment. People were able to rediscover common causes. Processes of contestation have taken many forms, ranging from dissent to various forms of group activism and social advocacy. Such precedents point toward a long civic tradition of thoughtful and impassioned critique regarding the validity of state policy and of ways of organizing community life that serve plutocratic factions.

Democratic contestation is a democratic skill that schools can foster because, as a form of dissent in a democracy, it is an expression of voice. Couldry (2010) discusses political deliberation and the need for "wider acts of retelling" (p. 147) and "acts of contention" (p. 148), while calling for democratic political exchanges that can transpire under conditions of vital disagreement with the forces of domination. As a form of political voice, engaging in civic contestation is part of learning to be on guard. As Sheldon Wolin (1994) explains, "democracy was born in transgressive acts, for the demos could not participate in power without shattering the class, status, and value systems by which it was excluded" (p. 17). Engaging in such intellectual disobedience exposes the injustices of various systems of oppression. Wolin's observation points toward the need for the constant telling of stories about how things could be otherwise and how unjust policies shape everyday lived experience.

Contestation efforts are actions that embody voice and enable autonomy. They involve questioning behavioral norms and evaluating the appropriateness of a variety of practices. When such autonomous practices thrive, the injustice of an established ideology and the system of justification upholding it become evident. Castoriadis (1997) conceives of autonomy in both an individual and collective sense as freedom; this freedom, as the basis of a democratic way of life, is based on when the public sphere "is effectively open to the participation of all" (p. 7). It follows that being autonomous does not mean being independent of the consideration of others, for it is in dialogue with others that we come to shared insights about the legitimacy of governmental authority. Being autonomous and being dialogic are entwined. Dissent and dialogue are interlocking processes. Engaging in autonomous thinking means freeing our thought processes from the yoke of unchecked authority.

\section{Questioning the Legitimacy of Unequal Community Flourishing}

Contesting the legitimacy of policies and modes of being in the world that fall out of the realm of what can be considered humane and just is at the core of what it means to educate and to become educated. Learning to challenge injustice is a vital aspect of supporting a democratic 
Krynski, A. (2019). In a State of Fragility: The Compromised Dignity of Communities, Indignation, and the Incapacitation of Public Education

mode of living. Public institutions of learning can take on true relevance as they induce communities to challenge their self-perception as independent bastions only marginally related to a larger polity of communities that ought to flourish. Instead of tending appeasingly to their meadows of complacency and complicity, such a shift in orientation means breaking down the fences holding in decades of privately felt moral indignation. Dissenting voices arise when a variety of views collide as they do every day in schools. Educators and students deserve to be able to express indignation publically without fear of being chastised and as a matter of educational routine and civic obligation. Understanding democratic contestation efforts is therefore vital to educational thought and practice.

\section{Visceral Indignation and an Epistemology of Emotions}

As communicative beings, silent indignation is not in our nature, and yet toned-down resentment has been a recurring societal tendency in Western industrialized nations. We cannot understand contestation efforts and how protest relates to public education without understanding the role emotions play in meaning-making. James Jasper (2018) offers a typology of emotions relevant to politics (p. 35) spanning reflex emotions, urges, moods, affective loyalties, and moral commitments. Jasper challenges conventional and wellentrenched notions that construct feeling and thinking as separate processes. Instead, he replaces this false dichotomy with the amalgamated term "feeling-thinking processes" (p. xi). This reconceptualization contests our understanding of emotions in political life as inevitably leading to turmoil and uncertainty, an understanding deliberately fostered since the dawn of democracy to malign and thwart people's collective agency. What emerges out of his project is, in effect, an epistemology of emotional energy that follows the regularity of the tides, is everything but impetuous, and is informative and comforting in the potential it offers to upset unjust living conditions.

No matter the general spirit of the times, be the seas turbulent or calm, all educators face the small child that displays deep-seated wonder in the face of distress and the adolescent slowly growing accustomed to the consequences of state-sanctioned and state-promulgated inequality. Tugging at our shirt, and expressed through their budding lexicon, small children ask visceral questions at the sight of a person living in a state of homelessness. Growing into adolescence, many such children become outraged at the societal acceptance of such a reality. In contrast, encountering similar scenes of suffering, fully-formed and vote-holding citizens might not register, and eventually actively avoid, the misery staring them in the face. Hurt and anguish, too painful to witness and not do anything about, diminish agency. Children learn to avert their gaze as they learn from our example. What they learn is skillful avoidance and expert unresponsiveness. A default mode of intergenerationally transmitted fatigued indifference sets in. It is this indifference, as Bauman (1989) explains, that as part cause, part symptom, and part outcome sets the stage for moral catastrophes.

Democracy cannot be sustained without respecting the child's tentative inquiry into the causes of suffering and the adolescent's growing indignation in the face of resigned complacency of an electorate they are soon to join. Whereas undemocratic forces will do everything in their 
Krynski, A. (2019). In a State of Fragility: The Compromised Dignity of Communities, Indignation, and the Incapacitation of Public Education

power to suppress signs of such sensitivity, a democratic society must value these moral intuitions. It is a danger to the ideal of democracy if a society does not. As Bauman (2000) notes, taking a "morally neutral stance" (p. 89) is equal to being complicit in the perpetuation of inequality. A supposedly democratically-minded government's paradoxical undermining of the very democratic public sphere which justifies its existence (a public sphere that it itself is appointed to guard) leads to the creation of a vacuum to be filled by a recurring set of shallow characters. Corporate activists and populist agitators seize the remnants of democratic public institution and public trust in elected government and deploy these societal and cognitive infrastructures for their own ends. Equipped with such fodder, politically ambitious persons may initiate movements that channel visceral indignation into expressions of violence through hateful rhetoric. This outcome is not inevitable. Writing about the Brexit vote in Great Britain, Paul Mason (2017) observes, "only by understanding the source of anger can you defuse it" (p. 96). Whoever shall be perceived to respect the people's indignation shall gain their trust, goodwill, and vote.

Indeed, rather belatedly, it has become clear that a formidable storm of indignation has already been forming across the world. A plurality of voices and motivations are enmeshed. Educators need to recognize that these ideas affect their students in their families and in their wider communities. Judging from current bestseller lists, political commentators and former statespersons are rushing to make sense of this ominous climate. Many are foreseeing the advance of a fascist deluge of Western democracies. Cultural critics observe that the decline in democratic commitment has been decades in the making. Arjun Appadurai (2017) posits a "democracy fatigue" (p. 7) setting in among citizens, a phenomenon he attributes to a modern culture of acceleration that no longer accommodates the "slow temporalities of democracy" (p. 8). When many people perceive democratic processes as inconvenient and statesperson politeness as out of step with our efficiently blunt times, why would citizens contest undemocratic rhetoric if its originators offer easy assurances and swift measures to erase what ails them?

Nancy Fraser (2017), evoking "electoral mutinies" (p. 40), lays out the equally unsatisfactory options available to voters as they wish to demonstrate their grievances. Fraser (2017) identifies a "progressive neoliberalism" (p. 41) characterized by a "faux understanding of emancipation" (p. 48) and a "reactionary populism" (p. 47) that seduces many but offers "no resolution to the present crisis" (p. 48). Fraser takes issue with progressive efforts that, in their quest for culture change, have left on the side of the road the dream and necessity of working toward economic equality and the attendant dignity due to all people. Chantal Mouffe (2019) proposes a populism of the left as a political strategy for Western Europe when she calls for a "mobilization of common affects in defence of equality and social justice" (p. 6). Both Fraser and Mouffe observe that there is potential in this political moment and in people's indignation for democratic reinvigoration.

In a similar vein, ethnographic studies reveal a variety of groups expressing widespread indignation at their diminished life chances and the particular ways in which they make sense of the causes they attribute as leading to such setbacks. Michael Kimmel (2017) paints a picture 
Krynski, A. (2019). In a State of Fragility: The Compromised Dignity of Communities, Indignation, and the Incapacitation of Public Education

of indignation that defines and permeates the lifeworlds of his participants. In particular, Kimmel (2017) focuses on how nostalgia, fading guiding images of reassuring masculinity and fulfilling motherhood, and white men's perception of "dispossession" (p. 9) of their partially lost entitlements contribute to a political identity that arises out of a visceral reaction to overall downward mobility. Through his conversations with participants, Kimmel (2017) identifies a conflation in their minds of greater social equality, perceived through distant and mediatized images, with increased class inequality, their lived reality. This perception is also evident in Arlie Hochschild's (2016) research when participants speak about feeling left behind, their lived reality, as they conclude that others "cut in line" (p. 137), a conclusion likely drawn based on repeated claims made by distant authorities they respect. In both research contexts, we see the merging of the pain of people's deeply felt reality with the comfort-inducing storytelling that distant meaning-making apparatuses such as people's preferred media outlets provide.

This line of inquiry takes seriously the real economic plight that affects people. As a response to the disdain coming out of the mouths of and shining through the policies of real or imagined elites, these difficulties lie at the heart of indignation. Appadurai (2017) sees an "accidental and partial overlap" (p. 2) in voters' apprehensions and populist leaders' promises. Fraser (2017) sees "mal-directed" (p. 46) rage where the root issues are so buried under a heap that the first person to be seen in its vicinity with a shovel appears as the hero who saves the day by appearing to do something, anything at all. Hochschild (2016), rejecting a simplistic hypothesis of gullibility (p. 14), suggests that "deep stories" (p. 16) of people's anguish reveal the complex constellations of factors contributing to the architecture of their beliefs. Kimmel (2017), identifying a pernicious process of "manufacturing rage" (p. 31), examines a concerted media effort to channel people's moral indignation into politicized anger. What emerges from this line of inquiry is the unearthing of deliberate efforts at camouflage and manipulation that lead to misattributions of the real causes of people's suffering. Kimmel (2017) stresses that people's grievances are "real" but not "true" (p. 9), in that their experiences are sincerely felt but inaccurately assessed.

Writing about social movements that express a variety of affective and moral commitments (Jasper, 2018, p. 4), Donatella della Porta (2017) explains how "anti-austerity movements" (p. $31)$ are in their protest and contestation inclusive and committed to democratic ideals. These groups differ from those who make up "regressive movements" (p. 37) that are in their protest and contestation exclusive, xenophobic, and committed to authoritarian models. Most importantly, della Porta (2017) emphasizes that upon probing, we find "the same discontent" (p. 37) fueling both factions' fires. There are then still options in terms of which protest movement someone might join or with which party's vision a voter might sympathize. Can those who perceive a vital need for sustained political action and who stand for inclusion and respect sway the cultural mood and the votes toward their side? As these various scholarly perspectives reveal, people's diverse perspectives on what is and is not being done to help them thrive is relevant to how learning communities understand their work as epistemic hubs that serve the needs of their communities and the larger web that makes up the polity. 
Krynski, A. (2019). In a State of Fragility: The Compromised Dignity of Communities, Indignation, and the Incapacitation of Public Education

\section{Silencing Indignation}

Learning communities that realize the importance of the political moment and their responses to it need to consider past institutional responses to indignation. Ideally, communication flows in both directions as confident democratic governance seeks out critique in order to bring about societal advancement. Just governments do not quell the expression of indignation. A society that fears dissent recasts principled ethical acts as impulsive unstructured incidents. These acts of civil disobedience are downgraded to the lowly and dubious status of unsophisticated outrage and threatening anger. Jasper (2018) points out that protestors have traditionally been portrayed as displaying fear and anger in a "panic model of emotions, the dark flip side of the exaggerated calculating-brain model of thought and rationality" (p. xi). Privileged groups, feeling threatened in the integrity of their social and economic vision, act swiftly to delegitimize efforts that might expose their decision-making as based in profiteering self-interest. When disenfranchised minorities fight to have their voices heard, these actions are cast as subversive; hence, the systematic civil disobedience of the Civil Rights movement in the United States is portrayed as individual riotous dissent (Kurashige, 2017; Robinson, 1987) and women's resistance to patriarchal oppression and structural and personal violence is attributed to supposed hysteria and surreptitious pledges to sorcery (Merchant, 1989).

In more recent times in the United States, we witness how indignation can also be silenced when group resistance efforts are portrayed as traitorous, disrespectful, and disloyal. Myths of moral superiority, propagated in schools, can serve to deflect questions about the legitimacy of policies and the adequacy and sustainability of prevalent oppressive and alienating modes of being-in-the-world. Through such discursive and material practices, powerful interests attempt to suppress visceral indignation through erasing its spontaneous (that is, democratic, in Wolin's sense) impulse by cruelly cutting short its potential "self-institution" (Castoriadis, 1997, p. 10) into a concrete lived democratic mode of existence. In essence, these instances of silencing indignation are examples of not honoring voice and of actively suppressing political participation, which Dalton (2017) sees as hurting the polity when "the loud voice of some drowns out the weaker voices of others" (p. 18) and, as a result, the government is ignorant of people's needs (p. 5). This means that absent an awareness of people's grievances, government is illiterate when it comes to reading the prevalent zeitgeist. As a result, government makes "suboptimal" (p. 5) decisions. In addition, whose voice is "weak" and whose voice is "loud" does not rest solely on numerical strength.

When majorities fight to have their voices heard, their indignation is similarly inconvenient to the authorities. But majorities in contrast to minorities are much harder to ignore and more difficult to silence outright. Both groups experience indignation, but numbers spell an advantage in terms of whose demands get acknowledged, even if not genuinely heard. This gives rise to the unfortunate conflation on the part of majorities suffering from economic hardship of their own lived experiences with those of historically violently oppressed groups. The self-perceptions of those understanding themselves to constitute a majority that has heretofore remained "silent" and that suffers from estrangement (Hochschild, 2016) from a changing country that has the potential to transform established voting power dynamics via 
Krynski, A. (2019). In a State of Fragility: The Compromised Dignity of Communities, Indignation, and the Incapacitation of Public Education

reforms can be fed by those wishing to appear to attend to people's concerns while downplaying the true sources of their suffering. Being encouraged to dub oneself a silent majority communicates clear undercurrents of threat and reminders of dormant potency, while reaffirming one's right and entitlement (see Kimmel, 2017) to and the legitimacy of a renewed, because clearly threatened (Krastev, 2017), "tyranny of the majority." This concept is worth revisiting per Lani Guinier's (1994) analysis of the original Madisonian skepticism about the beneficial effects of universal suffrage, as she herself has also done to demonstrate its relevance to questioning the ideal of meritocracy in higher education (Guinier, 2015).

Dalton (2017) sees this concern about the end of self-disfranchisement as resurfacing in contemporary debates when he states that "elite pessimism about democracy continues" ( $p$. 213). This is a pessimism and a silencing mechanism that Jasper (2018) terms "democracy's shadow" (p. 171). On the one hand, we wish to empower everyone, but at the same time, we fear the supposed irrationality of the masses and how they will influence the group's vision of progressive politics. Dalton (2017) explains how unequal participation in democratic processes has allowed governments to ignore the needs of various groups making up the polity. Once these fears are sown, unequal participation does not strike us as quite as dire a state as it is. The affluent minority establishes its own tyranny as its prominence eclipses the reality that all of us have become victims of its cultural dominance and political agenda-setting. Speaking about dominant majorities within democratic systems, Kathleen Sullivan (2009) notes that a pluralizing feminist philosophy can chip away at what she calls the "gentle democratic tyranny of public opinion that arises from the sameness of democracy" (p. 201). Natalie Masuoka and Jane Juhn (2013) understand this public opinion to be "the product of group interactions and historical memory structured by the person's position in the American racial order" (p. 3). Whoever wishes to silence indignation in a democratic society will have to shape public opinion as a factor that also has the potential to mitigate the relatively weak position in which minority groups find themselves in a democratic political system. All of this points toward the importance of asking how the work of learning communities shapes public opinion. This beckons the question to what extent schools can mitigate some of the issues scholars raise about the problematic nature of public opinion in a democracy.

\section{The Work of Communities and a Responsive Public School Ethos}

Given these concerning cultural conditions, one would expect schools to be places in which we can attempt to make sense of the political currents of our times. This is not so in a politicized school climate where the official goals of public education appear petty when they should never be. Theodor Adorno (2005) articulated this most pointedly: "every debate about the ideals of education is trivial and inconsequential compared to this single ideal: never again Auschwitz" (p. 191). This "never again" is the essence of moral indignation and should strike a chord with a subjugated citizenry. Instead, we find widespread acceptance of schools that suppress indignation, avoid difficult questions, and do not dare critique openly and with confidence unethical state policy and associated modes of being-in-the-world. This makes difficult the articulation of a public ethos that allows schools to advocate for a citizenship ideal that is rooted 
Krynski, A. (2019). In a State of Fragility: The Compromised Dignity of Communities, Indignation, and the Incapacitation of Public Education

in ethics, a tradition of successful civil disobedience, nonconformity, and depth of thought conducive to autonomous ways of being.

Such an ideal of ethical responsiveness requires, at a minimum, a form of democratic education that gives schools shared authority with parents to decide what is important for students to learn (Gutmann, 1987). However, ethical responsiveness involves deep critique of harmful cultural trends that are sure to challenge some parents' sensibilities. As our emergent political realities paint a picture of deeply felt injustice, how do educators weave discussions about this "orientation toward the world" (Jasper, 2018, p. 120) into the institutional fabric? A public school ethos that captures the motivation behind moral indignation and sees it for the common denominator it can be is true to the sense of "public" as connecting all members of the polity. To achieve this aim, public schools must honor voice and cultivate dialogue to counter a pervasive divide-and-conquer ethos that denies commonalities and disregards our political level of existence. Such an orientation requires a sense of advocacy that is based in intergroup connection. One of the essential questions citizens should ask themselves is to what degree their felt indignation corresponds to the felt indignation of their fellow citizens. Educators need to pose this solidarity-sparking question to students to encourage the development of ethical solidarity as a democratic mode of being.

Political beings are aware of the role of assent and dissent in a democratic system and learn how to express both in everyday life and in moments of concerted public effort at political communication. Just as social movements provide such venues, public education also holds the promise of allowing us to communicate our grievances and search for democratic solutions together. As settings in which we can enact democracy, schools have the potential to be sites of democratic contestation. Despite his often disillusioning account of democratic governance, Wolin (1994) posits a definition of democracy that is well suited to theorizing democratic modes of being in public education. According to Wolin (1994), "democracy is a project concerned with the political potentialities of ordinary citizens, that is with their possibilities for becoming political beings through the self-discovery of common concerns and of modes of action for realizing them" (p. 11). A responsive public school ethos encourages such necessary protest and ensuing dialogue.

The complexity of the political emotional landscape as it shapes civic identity requires of us dialogic inquiry anchored in careful ethical deliberation. This includes countering indifference about public issues with an ardent commitment toward the world (Bourdieu, 2000). It also includes engaging students in conversations to examine the degree to which a world of consumption attempts to erase visceral indignation. If we wish to be ethically responsive, we cannot rely exclusively on the cultivation of personal virtues. Van Hooft (2006) insists that any ethical project must strive to reconcile virtue and justice (p. 110). Justice, in Jasper's (2018) conceptualization, is "how people are treated when they interact" (p. 130). According to Paul Ricoeur (1994), justice "extends further than face-to-face encounters" (p. 194). Dialogic inquiry is essential to an education that enables children to learn how to interact with those they love and with those to whom they commit morally (Jasper, 2018, p. 128). Dialogue based in moral commitment fosters a sense of being-in-community with others. Dedication to a public ethos 
Krynski, A. (2019). In a State of Fragility: The Compromised Dignity of Communities, Indignation, and the Incapacitation of Public Education

suggests an obligation to the common good as an extension of the care we usually reserve for those within the city gates. An impassioned public school ethos can provide the fertile ground needed to nurture ethical advocates who will redefine what the gates mean. As Bauman (2001) writes poignantly, "security sacrificed in the name of freedom tends to be other people's security; and freedom sacrificed in the name of security tends to be other people's freedom" (p. 20). In contrast, an ethically responsive ethos takes everyone's needs into consideration.

Because indignation and teaching are affective and relational processes at their core, educators can work to expose government and community apathy toward injustice as part of their educational practice. This is a possible outcome of appealing to students' sense of what is just, our conscience Thoreau (1992) saw as being able to guide us toward more just decisions than the amalgamated opinions of the political majority ever could. The development of such a public conscience requires, as Castoriadis (1997) maintains, a "political educational process" ( $p$. 11) that strives to develop "corresponding abilities" (p. 11) in emerging citizens as they participate in the democratic process. These abilities do not simply inform a democratic modus operandi, Castoriadis explains, but go deeper as they shape citizens' conceptions of political equality. We can draw parallels here to Anderson's (2010) insistence on engaging in political philosophy through problem-oriented and empirically informed "non-ideal theory" (p. 3). Anderson (2010) points to the importance of starting with "a diagnosis of injustices in our actual world, rather than from a picture of an ideal world" (p. 3) and sees this process as consisting of explanations of causes and mechanisms and identifications of "the responsibility of different agents to alter these mechanisms" (p. 22) and, lastly, undo them. Taking cues from the realm of political philosophy and Anderson's (2010) methodological approach, we can begin to imagine a non-ideal approach to teaching about how communities ought to relate to one another. Such an approach is rooted in contestation, advocacy, and democratic institutional agency that defies rationalizing storytelling.

\section{Ethical Advocacy as an Affirmative Practice}

A responsive public school ethos carves out space in schools for the cultivation of both contestation and advocacy. As a grassroots ethical and political practice, advocacy is an affirmative practice because advocacy honors voice. When we teach for advocacy rather than categorically treating everyone's voice as equally valid, we treat everyone's voice as equally worthy of being ethically probed. We tell our intertwined stories and engage in processes of "retelling" (Couldry, 2010, p. 147) to develop and amplify our civic voices. We can encourage such habits through educational practices that respect moral indignation as integral to our ethical development. We pay attention to moral emotions because, as Jasper (2018) puts it in clear terms, "it feels good to do the right thing" (p. 5). At the risk of sounding politically naïve, we should not discount that what we feel and think in reaction to injustice takes on a public dimension and public relevance. As community challenges increasingly coalesce with global concerns, a commitment to the public dimension of community life brings with it planetary commitment. Engaging in a sustained and collaborative thought process in our educational institutions allows us to cultivate an ethic with which to approach such boundary-crossing challenges. Such an ethic is rooted in place and gives rise to local responses to the crises of our 
Krynski, A. (2019). In a State of Fragility: The Compromised Dignity of Communities, Indignation, and the Incapacitation of Public Education

times. Yet, it examines the cosmopolitan condition (Beck, 2016) of identifying "'world problems" (Beck, 1999, p. 15) as reverberating in our local places without hiding their global scale.

\section{Educational Practice as Advocatory Work}

A teacher identity that encourages critical thought rests on the willingness of educators to probe deeply within to identify their own sources of indignation and how these motivate their work. Becoming a teacher requires a commitment to initiate conversations about the legitimacy of policies and unjust ways of being-in-the-world. Teachers who examine the role moral emotions play in past and present protest and political action (Jasper, 2018) do important work to help their students develop such understanding. Such educators challenge a culture of apparent indifference and outward half-heartedness. As a case in point, Paul Gorski (2018) distinguishes between spheres of influence (p. 177) in teachers' work; teachers have control over certain material aspects of their practice, but "another commitment is developing deep understandings of the barriers outside our spheres that impact students within them" (p. 178). With such understanding of obstacles comes a commitment to "not replicate them unwillingly" (p. 178). This is an example of ethical responsiveness through an advocatory process Gorski (2018) calls "expanding our spheres of influence" (p. 177). This process serves to support a variety of equity and justice commitments.

What teachers need to engage in advocacy work is the support and protection of the institutions in which they work. No matter their age, many students look to their teachers to see if they are as affronted by the state of things as they are. Many educators are but are not free to show it lest they raise topics deemed controversial (see Hess, 2009), or rather, when they upset the worldviews (especially the economic and social visions) of members of the communities in which they teach. This not only infantilizes the teaching force, it constitutes one of the challenges of reimagining public schools as community schools. Public school teachers are committed to being facilitators of dialogue, but they may worry that their commitment to justice has no place in their teaching practice. This practical concern of a figure invested with authority wishing to provide a safe classroom atmosphere is not the same as requiring public school teachers to be, as is often ambiguously termed, "neutral." For educators, disclosing political affiliations can be counterproductive. Disclosing one's identity as an ethical thinker is vital. Demonstrating ethical neutrality is out of the question. It is often precisely those people who profess distaste for moral relativism who are the first to call for educators and schools to remain neutral in times of moral upheaval. As teachers model and encourage ethical citizenship, they advocate for just living conditions precisely because they respect students' various backgrounds.

\section{Incapacitating Public Schools}

Such a view of education and teacher identity goes against commonly accepted educational paradigms. Many adhere to the view that it is not up to public institutions to invite students to contest the legitimacy of state policy, market-based modes of being, and a world of economic and political inequality. David Archard (2015) identifies a fear in a liberal society of "a single 
Krynski, A. (2019). In a State of Fragility: The Compromised Dignity of Communities, Indignation, and the Incapacitation of Public Education

collectivist ideology" (p. 240) driving public education. It is not up to schools, the well-known argument goes, to evaluate the adequacy of state responses to a variety of contemporary issues and to offer opportunities for critique lest schools inculcate particular perspectives. Any mention of politics evokes not ethical and civic concerns but party-political doctrines. This, according to Archard (2015), means that any attempt to tailor teaching to bring out cooperation, group well-being, and striving for equality is conflated with indoctrination into one demonized ideology. As a result, educators are categorically not to challenge inequality, among a long list of other taboo subjects, and to stay off the prohibited terrain of encouraging protest of those suffering indignities, in particular if they happen to live in the vicinity. Educators are not to ask students to probe too deeply into this rarely clearly delineated terrain. Instead, they are to transmit a certified body of information only thinly disguised as stateapproved standards. Such prohibitions cut deeply into how teachers working in particular learning communities understand the nature of their work.

Teaching in such a state is like navigating a minefield. What pervades the field is an overall lack of political vision for the institutions into whose care we entrust our young people. A shared political identity might lead us to ask who planted the mines and for what reason and how we can work together to remove them. It would involve understanding motivations, emotional undercurrents, and why people avoid unpleasant emotions (Jasper, 2018, p. 95). Barring public education from doing this is an educational arrangement that is anathema to democratic ideals and equals inconsequence. It is a short step from here to arguing away the relevance of funding public schools altogether if all they are supposed to do is prop up individual students.

Public schools remain incapacitated to foster nuanced understanding in the citizenry of the persistence of pervasive inequality and calamitous decision-making on the part of successive political administrations. In people's minds, such administrative incompetence equals government inadequacy. In Charles Tilly's (1998) analysis, in a democracy the ruling classes comprise a significant number of high-status groups. This phenomenon of the thriving of oases of well-being in a desert of unmet needs discourages the raising of questions about inclusion and exclusion in our public schools. Educational policy reroutes public funds toward the maintenance of the country's artificial oases and feeds what Tilly (1998) refers to as the "exploitative side" (p. 193) of democratic government. This translates into, as David Labaree (1997) explains, discourse about public education in the United States being dominated by what he calls a "social mobility goal" (p. 50), a paradigm that works against the "ideal of civic virtue" (p. 65). Labaree (1997) details how public education is increasingly posited as a private good rather than a public good. Bauman (2013), considering why there is little resistance to the worldview that ultimately feeds these ideas about the purpose of education, identifies three responses in the face of injustice-resistance, submission, and collaboration-and comes to the conclusion that the promise of mobility and the "precious currency of social acceptance, position and prestige" (p. 26) overshadows the option of resistance. Market ideologies, when invoked in schools, lure people into a system that makes no room for critique. In times of rampant economic inequality and downward mobility and the presence of widespread moral indignation, public education for "democratic equality" (Labaree, 1997, p. 43) takes on renewed relevance. 
Krynski, A. (2019). In a State of Fragility: The Compromised Dignity of Communities, Indignation, and the Incapacitation of Public Education

\section{Education in a Fractured Polity: Fragmentation, Fortified Communities, Ownership}

Larger intercommunity dynamics play an important role in understanding civic dissent efforts. When we search for ways to support democratic contestation efforts in public schools, we engage in what Maria Lugones (2000) has described as a "process of reconsidering the place and meaning of community and home within a politics of resistance and liberation" (p. 467). Living in a community indicates demarcation whereas living in community points toward connection. Even if we engage students in conversations about the necessity of just governance, we may not ask them to look inward and examine their own thinking about being-in-community with others. Yet, it can be argued, as Adorno (2005) maintained, that "the only education that has any sense at all is an education toward critical self-reflection" (p. 193). If we were to engage in such self-reflection, would we find the old community image of a cordoned-off, fortified town in our supposedly democratically-oriented minds?

Without working together to confront this lingering guiding image, we will likely not arrive at a concrete resolution of unequal living conditions in and among our communities. In a system in which communities have varied degrees of political clout, turning inward contributes to the fragmentation of the greater political community. As each community sustains its own schools, it risks losing a sense of embeddedness within a greater polity. When schools do not develop an ethos for a greater whole, then we cannot expect young people to carry in them an ethos that will cause them to identify with this greater whole as adults. Bauman (2013) notes the faulty view of people being understood as having "different abilities by nature rather than having different capacities to develop their potential because they are cast in different social conditions" (p. 22.). If we accept that there will be communities that are prevented from offering a particular baseline quality of life for their residents by way of their geographic location and historical trajectory, we have acquiesced to unlink from the polity as a web of affiliation and attachment.

This is the opposite of democratic contestation of injustice and a tendency Bauman (2000) warned about when he spoke about the "departure from politics and withdrawal behind the fortified walls of the private" (p. 88). Bauman's admonition critiques a frame of thinking that, if left unchecked, by way of justifying a withdrawal from a shared project, contributes to the weakening of democracy. When the affluent few retreat to an ultra-private sphere of gated communities, exclusive neighborhoods, and affiliated - in effect, privately sponsored-schools, they continue to benefit from the relative safety and freedom democratic systems provide. But as supra-citizens with blank checks and no obligations, they do not concern themselves with the difficult work of preserving these democratic privileges. The rest of us are tasked with carrying the democratic torch through the storm.

The fragmentation of the larger polity is predicated on foregrounding ownership as a mode of being in the world. Ownership rests on separating a former whole into parts. Bauman (2013) notes that the gap between the rich and the poor has transformed into "a picture of two worlds, with few if any interfaces or meeting points between them, and so also with their inter- 
Krynski, A. (2019). In a State of Fragility: The Compromised Dignity of Communities, Indignation, and the Incapacitation of Public Education

communication all but broken" (p. 14). This hyper-separation fosters a way of being-in-theworld that is based on recasting selfishness as a virtue. It also assures the continuity of hereditary wealth as a guarantor of having the illusion of a better life than others and, thus, the persistence of a pernicious social determinism that allows some greater power to legitimize policies that ensure their own continued thriving.

Fragmentation permeates all aspects of public education. The very idea of school districts and their ensuing attendance boundaries precludes such a community ethos. In demarcating boundaries, we set to protect what is ours. We fortify the private and unlink from the polity. It is this process that we must continue to critique. This is particularly the case in a school system partially funded by local property taxes, in which residents might develop a sense of purchasing educational services as they have come to think of purchasing other commodities. An ownership framework reinforces schools as firmly planted on service industry terrain and teachers as service providers. The ensuing unequal customer and client relationship does not allow for teachers to subvert their own role as already minimal agents of the state. This ownership model can also be superimposed on the parent-child relationship (Archard, 2006, 2015). But if we posit that children are not the automatic extensions of their parents and their values, schools ought to have the right to challenge the community and introduce children to a variety of points of view. For when children enter our public schools, they encounter a different sphere of influence, using Gorski's (2018) shade of the expression. If children do not learn to respect other points of view in a public space, they become voters who get to decide for all of us without knowing about all of us. Public schools cannot be trapped in a loyalty to their community that precludes the intellectual space necessary for supporting a democratic public ethos. Teachers need to respect the communities in which they teach without being completely beholden to them.

\section{Establishing Connections: Dialogue, Vulnerability, Intercommunity Solidarity}

"This notion of dialogue and common consciousness suggests that there is some way out of our collective difficulties. And we have to begin at the grass roots, as it were, not to begin at the top of the heap with the United Nations and the President" (Bohm, 1996, p. 41).

To counter a system of inequality and its manifestation in unequal communities, public schools as institutions need to be actively in community-and thus outwardly communicative and in dialogue-with one another. This requires overcoming decades of competitive thinking, for communities and schools that are hermetic are incapacitated to keep the fire of the democratic spirit burning. It is in a horizontal embrace, not in vertical tower building, that public education can cradle the fragile state of democracy. It is this kindness and respect we want to model for young people as they learn to establish respectful interpersonal and intergroup relationships and develop mutuality in an integrating (Anderson, 2010) political community.

Here is the potential for those elusive and spontaneously arising moments that Wolin considers to be constitutive of a vibrant democracy. They can be found when people come together and, as Wolin (1994) puts it, "through public deliberations, collective power is used to promote or 
Krynski, A. (2019). In a State of Fragility: The Compromised Dignity of Communities, Indignation, and the Incapacitation of Public Education

protect the well-being of the collectivity" (p. 11). Establishing connections within and among communities is necessary to create a political spirit of solidarity to counteract destructive cultural tendencies that further fracture the polity. In the absence of a sense of interconnectedness, we harm our chances to strive for justice, but a call for social cohesion can be a reminder to many marginalized groups of the imposition of a dominant culture. To distinguish between such an ideology and an intercommunity solidarity anchored in autonomy that acknowledges interdependence, Teena Gabrielson (2016) proposes a conception of agency as "relational, socially distributed, and embodied" (pp. 399-400). In this conceptualization, communities ultimately decide to what degree they would like to join any wider effort to work together.

Establishing connections to achieve intercommunity solidarity goes hand in hand with an awareness of shared vulnerabilities (Beck, 2016). More a necessity than a choice, Beck (2016) sees the intensification of global risks leading to what he calls "moments of shared fate" (p. 59). These moments allow us to establish meaningful connections. A sense of urgency compels us toward collective agency as the interests of one community intersect with the interests of other communities when it comes to access to water, for example. As Patricia Hill Collins (2013) notes, such intercommunity solidarity might lead to "coalitions of conscience" (p. 242), which she describes as rooted in ethical frameworks. As communities work together in coalitions to counter common threats in reaction to and anticipation of boundary-crossing crises, being in community with others has the potential to become a genuinely supportive mode of existence.

\section{The Collective Agency of Public Schools: Shared Aims, Authorship, Freedom}

Such a vision for being-in-community is predicated on fostering relational modes of being in and through public institutions of learning. We can conceive of autonomy and agency as individual and collective endeavors. It follows that autonomy and agency are just as much personal projects as they are institutional potentials and vital characteristics of a democratic polity. Public education is in need of a conceptualization of such collective institutional agency because such an orientation allows us to address shared goals and a common vision of justice for all communities while also respecting our different needs. How can public schools generate such agency?

We must search for a conceptualization of agency that is appropriate to educational contexts and their potentialities and constraints as well as the developmental readiness of children and their safety. Ruth Lister (2004) proposes a definition of agency as individual and collective "authorship" (p. 126) that brings with it a "capacity to act" (p. 124). Authorship implies a search for meaning, an orientation different from consumptive modes of being in the world. As people mutually engage when they gather together in schools, they work in community to generate and sustain authentic modes of being-in-the-world. This is authorship that defies conventions reminiscent of Bauman's (2004) understanding of agency in terms of making choices about "the way we live" (p. 31), particularly what kinds of modes of being we as social actors privilege. Bauman focuses on freeing ourselves from market-based ideologies, on not letting our lives become scripted as a result of passive consumption. To Lister (2004), agency consists of taking 
Krynski, A. (2019). In a State of Fragility: The Compromised Dignity of Communities, Indignation, and the Incapacitation of Public Education

strategic actions to fulfill social objectives. At these intersections, Bauman and Lister are both concerned with the particularity of life designs, as these open up what Castoriadis (1997) theorizes to constitute a break with "a closure of meaning" (p. 4). Castoriadis sees such shutting down of creative thought as preventing questions to arise that are, in effect, "mentally and psychically impossible for the members of that society" (p. 4). A democratic revolution is a break with this closure through which "any source of meaning other than the living activity of human beings" (p. 4) is rejected. Such collective agency is authorship. It is also dissent. As Castoriadis (1997) further maintains, "it therefore implies the rejection of all 'authority' that would fail to render an account and provide reasons, that would not offer de jure justifications for the validity of its pronouncements" (p. 4). This requirement points to authorship as a form of voice (Couldry, 2010) that breaks the molds in which we encase our educational aims.

Public schools can provide the literal and metaphorical pen and paper that enables such authorship if a child's parents or guardians can't currently afford pen and paper, or if they are in effect dictating what their children are to write. As democratic institutions, schools have a capacity to act if they have the freedom to animate just ways of being-in-community. Schools require autonomy to make choices that nurture a democratic spirit. This requires a degree of independence from local communities. Schools ought to have the right to challenge the communities in which they are located, even if those communities partially fund them, just as children have the right to challenge the parents who clothe and feed them. Institutional agency in schools consists of the ability to contest wider societal phenomena and continuously carve out a public ethos rooted in ethical interactions. Schools display agency when they encourage educational practices that dispute the legitimacy of unethical modes of being in the world and expose associated practices, discourses, and relationships. Schools also exhibit agency when they become spaces in which calling out unethical policies becomes the order of the day.

\section{Ethical Oversight and the Work of Public Schools}

In times of widespread moral insensitivity and "adiaphorization" (Bauman \& Donskis, 2013, p. 40), a process that Bauman and Donskis understand as a form of rationalization resulting in the boycotting of ethical concerns and the positing of a judgement-free consumer zone, it is to schools that we need to look to forge ethical paths for the polity. In an era of weakened unions and a polarized media landscape at war with itself, public schools remain standing as one of the few lines of defense. In a deliberate attempt to help young people channel indignation into a commitment to justice, through an ethical advocatory conception of public education, we can cultivate habits in emerging citizens so that they may take up advocacy for just communities everywhere.

In so far as schools engage students in contestation efforts, they can be said to take on an informal oversight function. As neoliberal governance superimposes market exchange behavior on interpersonal interactions (Harvey, 2005), it distracts from the necessity of engaging in ethical inquiry and attempts to eliminate those spaces in which such questioning can occur. Neoliberal ideology rewards undignified policies and practices. The core democratic skill of being willing to question and to raise questions, as Castoriadis (1997) explained, is essential to 
Krynski, A. (2019). In a State of Fragility: The Compromised Dignity of Communities, Indignation, and the Incapacitation of Public Education

learning to be individually and collectively autonomous. Public schools are threatened in part because they provide such space. Walter Parker (2010) maintains that by engaging with other people in dialogue in schools, we "reclaim and reconstitute the democratic public sphere as a fertile site for political critique and action" (p. 2831). When the work of communities includes a commitment to connection, schools become places in which we can find and learn to appreciate democratic community.

In this essay, I argue that public education is incapacitated to fulfill its vital role as a democratic institution. First, I maintain that public education presently does not provide a space that allows for critical inquiry into the legitimacy of what are unethical, unjust, and unsustainable modes of being in the world. This type of critical inquiry would support civic dissent at the grassroots school-yard level. Dissent as a form of inquiry is only one part of the larger advocacy puzzle. I also see the need for an institutionally-grown advocacy of connection that nurtures intercommunity solidarity. Second, I propose that public education cultivate ways-of-being that are based in a conceptualization of distinct communities as being in connection with others and forming a greater polity. This type of orientation respects self-determination of communities while also embedding community identity within a larger web of affiliation and care. Finally, I suggest that public education take on an informal function of ethical oversight rooted in a strong sense of collective institutional agency. Through such agency, schools can recognize and respect and help us work through past and present civic grievances.

Teachers can foster this commitment to advocacy in those they encounter daily through their professional practice. Besides advocating for structural change, learning communities can take concrete steps to construct a public school ethos conducive to democratic life that enables teachers to do the following:

1. Extend social-emotional teaching and learning to include analysis of the political dimension of emotions. Teach children to be aware of the larger role emotions play in civic life. Jasper (2018) offers a typology for conceptual clarity, clearly distinguishing between affective and moral commitments while also presenting a historical overview of how emotions have been portrayed negatively for the purpose of political manipulation. Scholarship in the tradition of the sociology of emotions (see Harris, 2015) can inform educational thought as to the nature of social-emotional processes at the political level of our existence.

2. Teach about the ethical significance of events that arise in the political moment. The experience of living in fragile times can evoke a variety of civic responses to undemocratic governance. It can legitimize surveillance. Whereas surveillance implies monitoring and supervision indicates distraction, vigilance rests on careful observation and attentiveness. Cultivating an attitude of attentiveness to issues of justice and inequality can counter a culture of negligence.

3. Build intercommunity solidarity. Love of place is an affective commitment (Jasper, 2018), giving rise to questions of how to live together in one's local community. But public education must also consider larger moral commitments as they reverberate throughout the polity (Ricoeur, 1994; van Hooft, 2006). This includes fostering an 
Krynski, A. (2019). In a State of Fragility: The Compromised Dignity of Communities, Indignation, and the Incapacitation of Public Education

ecological sensibility that supports a sense of common vulnerability, care, and crossboundary connection. This sensibility includes an awareness of the unequal distribution of risks (Beck, 2009, 2016; Taylor, 2014) that affect impoverished communities.

A public school ethos influences how learning communities conceive of their work. Although public schools are frequently incapacitated to take on ethical advocacy aims, this incapacitation does not equate with an incapacity to act. Public schools can provide needed spaces for cultivation of connection and solidarity. As an ethical response to injustice, boundary-crossing conceptualizations of community encourage discourses and practices of connectedness as one way in which we can work to overcome relational inequality (Anderson, 2010; Tilly, 1998). Public schools can help cultivate in children a sense of ethical advocacy through a public school ethos of intercommunity solidarity so that visceral indignation does not fade and become subdued indifference or transform into expressions of hatred as it has many times, with tragic consequences, in our shared history. 
Krynski, A. (2019). In a State of Fragility: The Compromised Dignity of Communities, Indignation, and the Incapacitation of Public Education

\section{References}

Adorno, T. (2005). Critical models: Interventions and catchwords. New York, NY: Columbia University Press.

Anderson, E. (2010). The imperative of integration. Princeton, NJ: Princeton University Press.

Appadurai, A. (2017). Democracy fatigue. In H. Geiselberger (Ed.), The great regression (pp. 112). Malden, MA: Polity.

Archard, D. (2006, March). The moral and political status of children. Public Policy Research, 13(1), 6-12.

Archard, D. (2015). Children: Rights and childhood. New York, NY: Routledge.

Bauman, Z. (1989). Modernity and the Holocaust. Ithaca, NY: Cornell University Press.

Bauman, Z. (2000). On writing: On writing sociology. Theory, Culture, \& Society, 17(1), 7990.

Bauman, Z. (2001). Community: Seeking safety in an insecure world. Malden, MA: Blackwell Publishing.

Bauman, Z. (2013). Does the richness of the few benefit us all? Malden, MA: Polity.

Bauman, Z. (2017). Retrotopia. Malden, MA: Polity.

Bauman, Z., \& Donskis, L. (2013). Moral blindness: The loss of sensitivity in liquid modernity. Malden, MA: Polity.

Bauman, Z., \& Donskis, L. (2017). Liquid evil: Living with TINA. Malden, MA: Polity.

Beck, U. (1999). World risk society. Malden, MA: Polity.

Beck, U. (2009). World at risk. Malden, MA: Polity.

Beck, U. (2016). The metamorphosis of the world. Malden, MA: Polity.

Bohm, D. (1996). On dialogue. London, UK: Routledge.

Bourdieu, P. (2000). For a scholarship with commitment. Profession, 40-45.

Castoriadis, C. (1997). Democracy as procedure and democracy as regime. Constellations, 4(1), 1-18.

Collins, P. H. (2013). On intellectual activism. Philadelphia, PA: Temple University Press.

Couldry, N. (2010). Why voice matters: Culture and politics after neoliberalism. Thousand Oaks, CA: Sage.

Dalton, R. J. (2017). The participation gap: Social status \& political inequality. Oxford, UK: Oxford University Press.

della Porta, D. (2017). Progressive and regressive politics in late neoliberalism. In H. Geiselberger (Ed.), The great regression (pp. 26-39). Malden, MA: Polity.

Ewing, E. L. (2018). Ghosts in the schoolyard: Racism and school closings on Chicago's South Side. Chicago, IL: The University of Chicago Press.

Fraser, N. (2017). Progressive neoliberalism versus reactionary populism: A Hobson's choice. In H. Geiselberger (Ed.), The great regression (pp. 40-48). Malden, MA: Polity.

Gabrielson, T. (2016). Bodies, environments, and agency. In T. Gabrielson, C. Hall, J. M. Meyer, \& D. Schlosberg (Eds.), The Oxford handbook of environmental political theory (pp. 399412). Oxford, UK: Oxford University Press.

Glaude, E. S. (2017). Democracy in black: How race still enslaves the American soul. New York, NY: Broadway Books. 
Krynski, A. (2019). In a State of Fragility: The Compromised Dignity of Communities, Indignation, and the Incapacitation of Public Education

Gorski, P. C. (2018). Reaching and teaching students in poverty: Strategies for erasing the opportunity gap ( $2^{\text {nd }}$ ed.) New York, NY: Teachers College Press.

Guinier, L. (1994). The tyranny of the majority: Fundamental fairness in representative democracy. New York, NY: The Free Press.

Guinier, L. (2015). The tyranny of the meritocracy: Democratizing higher education in America. Boston, MA: Beacon Press.

Gutmann, A. (1987). Democratic education. Princeton, NJ: Princeton University Press.

Harris, S. H. (2015). An invitation to the sociology of emotions. New York, NY: Routledge.

Harvey, D. (2005). A brief history of neoliberalism. New York, NY: Oxford University Press.

Hess, D. E. (2009). Controversy in the classroom: The democratic power of discussion. New York, NY: Routledge.

Hochschild, A. R. (2016). Strangers in their own land: Anger and mourning on the American right. New York, NY: The New Press.

Ignatiev, N. (2009). How the Irish became white. New York, NY: Routledge.

Jasper, J. M. (2018). The emotions of protest. Chicago, IL: The University of Chicago Press.

Kimmel, M. (2017). Angry white men: American masculinity at the end of an era. New York, NY: Nation Books.

Krastev, I. (2017). Majoritarian futures. In H. Geiselberger (Ed.), The great regression (pp. 6577). Malden, MA: Polity.

Kurashige, S. (2017). The fifty-year rebellion: How the U.S. political crisis began in Detroit. Oakland, CA: University of California Press.

Labaree, D. F. (1997). Public goods, private goods: The American struggle over educational goals. American Educational Research Journal, 34(1), 39-81.

Lister, R. (2004). Poverty. Cambridge, UK: Polity Press.

Lugones, M. (2000). Community. In M. Jaggar \& I. M. Young (Eds.), A companion to feminist philosophy (pp. 466-474). Malden, MA: Blackwell Publishing.

Masuoka, N., \& Junn, J. (2013). The politics of belonging: Race, public opinion, and immigration. Chicago, IL: The University of Chicago Press.

Merchant, C. (1989). The death of nature: Women, ecology and the scientific revolution. New York, NY: Harper One.

Mouffe, C. (2019). For a left populism. London, UK: Verso.

Parker, W. (2010). Listening to strangers: Classroom discussion in democratic education. Teachers College Record, 112, 2815-2832.

Pimpare, S. (2011). A people's history of poverty in America. New York, NY: The New Press.

Robinson, J. A. G. (1987). The Montgomery bus boycott and the women who started it: The memoir of Jo Ann Gibson Robinson. Knoxville, TN: The University of Tennessee Press.

Ricoeur, P. (1994). Oneself as another. Chicago, IL: The University of Chicago Press.

Sullivan, K. (2009). Toward a generative theory of equality. In J. Locke \& E. H. Botting (Eds.), Feminist interpretations of Alexis de Tocqueville (pp. 199-223). University Park, PA: The Pennsylvania State University Press.

Taylor, D. E. (2014). Toxic communities: Environmental racism, industrial pollution, and residential mobility. New York, NY: New York University Press.

Thoreau, H. D. (1992). Walden and other writings. New York, NY: Modern Library.

Tilly, C. (1998). Durable inequality. Berkeley, CA: University of California Press. 
Krynski, A. (2019). In a State of Fragility: The Compromised Dignity of Communities, Indignation, and the Incapacitation of Public Education

van Hooft, S. (2006). Understanding virtue ethics. Stocksfield, UK: Acumen.

van Hooft, S. (2007). Cosmopolitanism as virtue. Journal of Global Ethics, 3(3), 303-315.

Williams, J. C. (2017). White working class: Overcoming class cluelessness in America. Boston, MA: Harvard Business Review Press.

Wolin, S. (1994). Fugitive democracy. Constellations. 1(1), 11-25.

Wolin, S. (2008). Democracy incorporated: Managed democracy and the specter of inverted totalitarianism. Princeton, NJ: Princeton University Press. 